\title{
REVEALING ORIGINALITY OF SONG WORKS: AN ANALYSIS TO THE COPYRIGHT LAW
}

\author{
Desrezka Gunti Larasati*
}

\begin{abstract}
* Teaching Assistant of Intellectual Property Rights Law and Researcher at the Faculty of Law, University of Indonesia.
\end{abstract}

Article Info

Received : 23 October 2014 | Received in revised form : 27 September 2014 | Accepted : 10 December 2014 Corresponding author's e-mail : derezka.larasati@yahoo.com

\begin{abstract}
The topic of this paper is to describe the defining criteria of originality of song works. The aspect of originality is important to make such work be protected by Copyright Law. In this research, the criteria to define originality are based on certain doctrines and/or theories of originality that may vary case by case. The use of such doctrines and/or theories is necessary, since the stipulations regarding originality in the Indonesian Copyright Act has not been considered suffice. With regard to the song works, the criteria of originality may be different from other works. Therefore, a comprehensive research on the characteristics of song as a work is also important. This research is a qualitative research with prescriptive design. The research depicts the use of certain doctrines and/or theories as supplementary provisions to the Copyright Law in defining the originality of songs, which have specific characteristics resulted from their author's creations and intellectuals.
\end{abstract}

Keywords: Copyright Law, Originality, Songs

\begin{abstract}
Abstrak
Topik makalah ini adalah untuk menggambarkan kriteria yang menentukan orisinalitas karya lagu. Aspek orisinalitas penting untuk membuat pekerjaan tersebut dilindungi oleh UndangUndang Hak Cipta. Dalam penelitian ini, kriteria untuk menentukan keaslian didasarkan pada doktrin dan / atau teori orisinalitas yang mungkin berbeda kasus per kasus tertentu. Penggunaan doktrin dan / atau teori-teori tersebut diperlukan, karena ketentuan mengenai orisinalitas dalam UU Hak Cipta Indonesia belum dianggap cukup. Berkenaan dengan karya-karya lagu, kriteria orisinalitas mungkin berbeda dari karya-karya lain. Oleh karena itu, penelitian yang komprehensif tentang karakteristik lagu sebagai karya juga penting. Penelitian ini merupakan penelitian kualitatif dengan desain preskriptif. Penelitian ini menggambarkan penggunaan doktrin dan / atau teori ketentuan tambahan Undang-Undang Hak Cipta dalam menentukan keaslian lagu, yang memiliki karakteristik tertentu yang dihasilkan dari kreasi penulisnya dan intelektual tertentu.
\end{abstract}

Kata Kunci: Hukum Hak Cipta, Orisinalitas, Lagu

\section{Introduction}

In order to be protected by Copyright Law, a work should be fixated (form a fixation; not just merely an idea) and have the originality. These requirements are in accordance with the Article 9 paragraph (2) of the Agreement on the Trade-Related Aspect of Intellectual Property Rights ("TRIPS"), and also Article 2 paragraph (3) of the Berne Convention on the Protection of Artistic and Literary Works ("Berne Convention"), which states about 'original' works. However, Berne Convention does 
not elaborate the criteria of a work to be considered as 'original.' Indonesian Copyright Law also does not stipulate clearly about the criteria of originality. Therefore, to deal with the case of originality of a work, the use of doctrines and/or theories of originality as references are necessary. Among some numbers of cases related to originality are the cases of so-called, 'song plagiarism,' happened either in Indonesia, or in other countries. Those cases of plagiarism raise some interesting legal issues of whether the songs that are sounded similar to others, are essentially created by copying or imitating from other song works, or the similarity is simply occurred because of coincidences. This is important for the protection of the songs, because the similarity may cause the songs become not 'original,' and therefore cannot be protected by Copyright Law.

To define whether a song is original, or having an originality, the defining criteria must first be considered. Since in general the international and national regulations of Copyright do not specifically stipulate such criteria, the first to be discussed will be the criteria of originality, which have been arisen based on doctrines and/or theories occurred as responses to deal with cases of originality of works. Then, the next to be discussed will be applying the most suitable criteria of originality to be used particularly in analyzing and defining originality of song works. Basically, the application of those existing theories and/or doctrines of originality was specific for certain type of works. However, it may also be possible to use such theories and/or doctrines to analyze the originality of other works, depending on the nature of the works itself. In this case, those theories and/or doctrines will be tested, of whether they can be used to define the originality of songs.

Furthermore, to analyze the originality of songs, it is also important to take into account the aspect of originality from the perspective of music studies. This is related to the characteristic of songs as a work different from other types of work. Thus, in assessing and applying the existing theories and/or doctrines to be used, originality based on music theories is considerably important. Moreover, the use of such theories and/or doctrines should also (essentially) in line with the Copyright Law in Indonesia. Even though there is no such an explicit stipulation of the criteria of originality for the songs, there is a stipulation regarding Copyright infringement, which touches upon the issue of originality; that a work which imitate or copy other work(s) is an infringement (a work which copied or imitated others cannot be considered 'original'), and the issue of the use of substantial part of the work.

The following sections will discuss about the case of song's originality as relate to plagiarism, theories and/or doctrines as well as jurisprudences on the criteria of originality, aspect of originality based on music studies, and analysis on the application of the most suitable theories and/or doctrines of originality to be used for song works. There will be several theories and/or doctrines discussed to consider a criteria of originality, namely: Sweat of the Brow (Industrious Collection); Creativity School; Skill, Judgment, and Labour; The Idea-Expression Dichotomy; The Theories of Circumstantial Evidence; and The Independent Creation Theory. Considering the characteristic of song works, perspective of originality from music studies, and taking into account the stipulations under the Indonesian Copyright Law regime, the Theories of Circumstantial Evidence and The Independent Creation Theory could be the most suitable criteria to define the songs' originality. The basic reason is because the Indonesian Copyright Act and perspective from music studies consider originality based on: (1) a qualitatively substance (substantial) assessment on the results, and (2) an assessment to the process of creation of whether it is originated from the 
authors, considering the relevant facts. The two mentioned theories could be the best tool to assess on the issue of such substantial (end) result of the song, and the process of song's creation. This argument will be further elaborated at the last section (Section 4).

This research on the most suitable/appropriate criteria of song's originality will be conducted both generally, as addressing the international context (also takes into account the international case), and particularly, as departing from the national copyright law and national case. The study will also in line with the concept of songs as the musical works, subject to copyright's protection. Through analyzing both the legal framework and the fundamental insights about the music (and songs), as well as the aspect of originality based on the theory in music studies, the appropriate criteria to determine the originality of songs could be revealed. It is expected from this research that the related stakeholders, including legal officers, and the society, can have an alternative reference in criticizing, concluding, and deciding whether certain songs, when they are sounded similar to others, are plagiarizing (or imitating) the other songs or just simply inspired by such songs. In this way, the research and analysis step further in contributing reference to define the originality of song works in the Copyright Law regime.

\section{Song Works and the Issue of Originality}

As mentioned previously, in order to be protected, a work must be in form of an expression - not merely an idea, ${ }^{1}$ and have the required originality. ${ }^{2}$ As regards to song works, ${ }^{3}$ the 'expression' means that the songs have been actualized as an audio wave that can be heard by human ears. This changes the perspective that in order to be protected, a song must be recorded into a physical media. Prof. Agus Sardjono, professor of Intellectual Property Law from the Faculty of Law, University of Indonesia, has recalled that a fixation of work not only can be conceptualized as something that can be seen or touched physically, but also works that can be heard using the sense of hearing, which in this case, applies to the song works. The physical phonograms or notations in form of music sheets are considered only as the media to record or physically keep the songs. However, the fixation of song itself happens by the time we can hear it. ${ }^{4}$

The songs, just like the other copyrightable works, have their own criteria to be

1 Article 9 (2) of the Trade Related Aspects of Intellectual Property Rights, and Article 1 para. (2) of Indonesian Copyright Act. No. 19 Year 2002.

2 Although Berne Convention on the Protection of Artistic and Literary Works of 1886 (lastly amended on 1979), does not define the criteria for originality of works, it indeed requires the works subject to copyright protection to be original, as stated in some of the stipulations: Art. 2 para. (3) - Translations, adaptations, arrangements of music and other alterations of a literary or artistic work shall be protected as original works without prejudice to the copyright in the original work. The criteria of originality then will be based on the national rules of Member States.

3 Song works are different with musical works. A song at least consists of melody and lyrics. Musical works could be divided as songs (music with vocals) and compositions (instrumental music). This means that musical works have broader definition than simply a song. (See Pono Banoe, Kamus Musik (Yogyakarta: Kanisius, 2003), s.v. "Lagu"; Don Michael Randel, ed., The New Harvard Dictionary of Music (Cambridge, Mass: Belknap Press of Harvard University Press, 1986), s.v. "Song"; and Desrezka Gunti Larasati, Penentuan Originalitas Ciptaan Berupa Karya Lagu: Tinjauan Hukum Hak Cipta, Skripsi, 2010, Fakultas Hukum Universitas Indonesia).

4 Prof. Dr. Agus Sardjono, S.H.,M.H., from the lectures of Copyright Law, held at the Faculty of Law, University of Indonesia, 2012. 
called as 'original' (or possesing the 'originality'), and this could be subject to debates since the Berne Convention does not specifically define the criteria for originality of a work, including song works. Addressing this issue, several doctrines of originality can help analyzing whether the respective works have the originality; thus visible for copyright's protection. These doctrines are used for cases in several common law countries, such as the United States, UK, and Canada. ${ }^{5}$ The Indonesian Copyright Act does not define the criteria for originality of works, however, in general the said works must have come from (or created by) the respective authors. ${ }^{6}$ The works created by authors in fixative forms are assumed to possess the originality, and therefore eligible for automatic copyright protection, unless other parties claim the copyright for the works.

In cases where there are songs sounded similar to each other, the analysis on the songs' originality becomes essential. If one of the similar songs is proven to be unoriginal, that song cannot be protected by copyright, and even can be alleged for infringement of copyright for copying the other songs. In Indonesia, there had been spotlighted discussions mentioning about song plagiarism in around 2008. ${ }^{7}$ The discussions touched upon issue of some Indonesian songs which were considered as sounded similar to some English songs, either from the United States or UK. ${ }^{8}$ As examples, an Indonesian band called D'Massiv was called as plagiarizing a song from United Kingdom's band, Muse, in one of their songs titled Dilema (plagiarizing from Muse's song titled Soldier's Poem). Another one is, also, an Indonesian band called Domino, which song titled Siapa yang Pantas, be said as similar to one of Muse's popular song, Starlight.

In this respect, the songs by D'Massiv and Domino are subject to further analysis of song's originality. This analysis of originality shall be based on certain criteria, which may be different with respect to the type of works. The criteria to analyze the originality of literature works may be different with the criteria of originality of song works. As regards to such case of songs plagiarism, the research will first questioning and exploring the appropriate criteria to decide on song's originality, then to apply such criteria in analyzing the case of alleged songs plagiarism happened in the last few years.

\section{The Aspect of Originality in Copyright Law Regime}

To begin with, originality differs from novelty. The requirement of originality does not mean a condition of non-exist, to become exist. Rather, the originality indicates an origin; whether the created works are originated, or come from the said authors. The criterion of novelty is used under the framework of patent, which protects the

\footnotetext{
${ }^{5}$ The doctrines and jurisprudences on originality help the creators or right holders prove their works are subject to copyright's protection, while for the court or judges, such doctrines can provide them references to asses the originality of certain works.

${ }^{6}$ Agung Damarsasongko, official at the Director General of Intellectual Property of Republic of Indonesia, Department of Law and Human Rights, on 14 October 2009.

7 The fact is, the songs are released before 2008, however, hot discussions occurred in 2008.

8 Among the examples of songs called by the society as plagiarizing the others, are: D'Masiv “Diam Tanpa Kata" vs Switchfood "Awakening", D’Masiv “Dilema” vs Muse "Soldier's Poem”, Dewa "Pangeran Cinta" vs Led Zeppelin "Immigrant Song", Vierra "Bersamamu” vs Westlife "Close," dan juga Dhani \& Chrisye "Jika Surga dan Neraka” vs Stephen Simmonds "Tears Never Dry." Musik Indonesia Plagiat? Introspeksi Buat Musik Kita, available at http://www.kaskus.us/showthread.php?p=122781951; Internet; Accessed on 7 April 2010.
} 
technological inventions encompassing product or process. Novelty, as one of the required conditions of patentability, refers to the newness (that the inventions have never been revealed before) of the functions or inventions which can solve specific problems. ${ }^{9}$ Thereby, the criterion or originality departs from different key concept with novelty. The originality in this context is also different with genuine or pure, which refers to authenticity of a work or product.

The Black Law's Dictionary ${ }^{10}$ defines originality as:

'(1) The quality or state of being the product of independent creation and having a minimum degree of creativity (originality is a requirement for copyright protection, but this is a lesser standard than that of novelty in patent law: to be original, a work does not have to be novel or unique);

(2) The degree to which a product claimed for copyright is the result of an author's independent creation.'

Such definitions state some qualities of being original, which are: as results of authors independent creations, and having degree of creativity.

As the US Supreme Court issued a jurisprudence concerning the originality of works: that "the work was independently created by the author and that it possesses at least some minimal degree of creativity","11 it can be stated that the originality refers to the process of creation by the authors that must be independent. To put in other words, the works are independently coming from the authors, which may reflect the authors' personality, as the results of authors' initiative, creativity, or imagination. This means that the originality involves in the issues of: (1) whether the works are originated from the authors, (2) who are deserved to be called as the authors from whom the works are originated, and (3) whether the said authors have put their creativities to the works.

The Indonesian Copyright Act of No. 19 Year 2002 mentions the works possessing the originality as those which are created from the authors' capability, creativity, and skills. ${ }^{12}$ In the new Indonesian Copyright Act of No. 28 Year 2014, it is also mentioned under Article 1.2 and 1.3, that a work created by an author should possess uniqueness and his/her sense of personality, which may come from his/her inspiration, abilities, thoughts, imaginations, skills, and so on. ${ }^{13}$ This means that to be called original, the works must not only originated from the authors, but also being created using some criteria of personality, abilities, creativity, imaginations, skills (and so on) of the authors. Even so, the Act does not define specifically the standard requirement of such personality, abilities, creativity, or skills which the works must possess. This could lead to varied standard depending on the categories of the works. Thus, doctrines, jurisprudences, and theories, either in Common Law or Civil Law countries, are being developed to address such issues. Indonesian Copyright Act has not formally absorbed

\footnotetext{
${ }^{9}$ Prof. Agus Sardjono, from the lectures of 'Patent law', 17 October 2012, Faculty of Law, University of Indonesia.

${ }^{10}$ Black's Law Dictionary, Seventh Edition (1999), s.v. “Originality”, by Bryan A. Garner (Editor in Chief).

${ }^{11}$ Copyright Protection Generally, Databases and the Law, Prof. Laura Gasaway's Cyberspace Law course at the UNC School of Law for Spring, 2006; diperoleh dari http://www.unc.edu/courses/2006spring/ law/357c/001/projects/dougf/node4.html;Internet; diakses pada 9 April 2009.

12 The Indonesian Copyright Act No. 19 Year 2002, General Elucidation, paragraph 6.

13 The research was conducted before the new Indonesian Copyright Act is enacted, however basically there is no essential difference regarding the issue of originality under the two Acts.
} 
any particular doctrines, jurisprudences, or theories yet. Therefore, to solve the case of originality, judges in the courts can have varied references from other countries, considering such references are in line with the Copyright Law regime of Indonesia.

The followings are some of the doctrines, jurisprudences, and theories particularly used in other countries to deal with the requirements and criteria of originality.

\section{A. Sweat of the Brow (Industrious Collection)}

Sweat of the Brow or Industrious Collection is one doctrine of originality which deems a work to have the originality, if the work contains its author's productive effort (labour), although in the absence of creativity. ${ }^{14}$ As an example, a 'phone directory' was considered as having the originality since it was created from the authors' labour in collecting information and arranging the numbers' directory. The criteria laid simply to the fact that the directory was originated from the authors, and they did not copy others. Thus, even though the labour needed mainly technical (with no creativity), as resulted from the collecting and arranging of phone numbers' information, the work was considered original. ${ }^{15}$ However, this doctrine was not considered sufficient to analyze a work's originality, since the standard criteria it determines is very low.

An opposition to the doctrine can be found in the jurisprudence of the US Supreme Court; the case of Feist Publications, Inc. v. Rural Telephone Service Co., 499 U.S. 340 (1991). In the case, Feist Publications, Inc. (or 'Feist') copied the white pages, which contained alphabetical phone numbers and city locations information, from the phone directory produced by Rural Telephone Service Co. (or 'Rural'). Rural then claimed for copyright infringement for Feist's action. In the white pages of 1983's phone directory produced by Feist, 1.309 of 46.878 phone numbers were the same with Rural's. Feist then stated that Rural's white pages were not original, therefore could not be copyrightable. In regards to this, the US Supreme Court elaborated in its jurisprudence that the US Copyright regime does not consider 'information' as copyrightable. The collection of phone numbers and city location as 'compilation of information' in Rural's white pages could not be protected by Copyright because it lacked originality.

For such collections of information to be considered original, and therefore copyrightable, they have to possess certain degree of creativity. Such creativity could occur in the process of 'selection and arrangement' of collections of information, including how it is presented, placed, or designed, so that the readers can read the information effectively. Therefore, the Rural's phone directory in its entirety, with elements of creativity in selection and arrangement, could be considered as having originality. However, merely the compiled information itself (in the white pages) which was copied by Feist, could not be considered original and copyrightable. ${ }^{16}$ From the case, it could be summarized that to have originality, the work must: (1) originated

${ }^{14}$ See a case of “U \& R Tax Services Ltd. V. H \& R Block Canada Inc.", (1995) F.C.J. No. 962, 62 C.P.R. (3d) 257 at 264: "a work must be original in order to be afforded copyright. Industriousness (Sweat of the Brow) as opposed to creativity is enough to give a work sufficient originality to make it copyrightable."

15 Abraham Drassinower, Sweat of the Brow, "Creativity, and Authorship: On Originality in Canadian Copyright Law," University of Ottawa Law and Technology Journal (2003-2004): 107-108.

16 Accessed from: Feist v. Rural, supreme.justia.com, and U.S. Copyright Law Precedent, Feist Publication, Inc. v. Rural Telephone Service Co.; available at http://www.solarnavigator.net/USA_copyright_precedent_feist_v_rural.html; Intenet; accessed on 11 September 2009. 
from the authors; (2) independently created, and (3) having some degree of creativity.

\section{B. Creativity School}

The Creativity School deems a work to have the originality, if the work not only contains its author's productive effort (labour), but also the element of creativity, although in a minimum standard. This doctrine occurs as opposing the Sweat of the Brow doctrine, because to consider a work to be 'original,' it must have at least element of creativity, and merely labour is not sufficient.

\section{Skill, Judgment, and Labour}

According to the doctrine of Skill, Judgment, and Labour, a work is deemed to have the originality if it is created based on the author's independent skill, judgment/ thought, as well as productive efforts. The assessment on the standards is a qualitative one.$^{17}$ Etymologically, Skill is a special ability possessed by someone which is resulted (for example) from training. Judgment relates to a person's critical distinctions, while Labour is a productive effort in creating the works. ${ }^{18} \mathrm{~A}$ case as jurisprudence from the English court dealt with a catalogue which contained an information 'compilation' on parts of motorcycles. The required Skill, Judgment, and Labour could be seen from the selection process; which information included or compiled in the catalogue. ${ }^{19}$ This means that the selection process must indicate some degree of Skill and Judgment, which in this case, by means of selection and/or arrangement on the compiled information. ${ }^{20}$

Other options that the English court considered, was to see the Skill and Judgment as relate to the individuality and personality of the authors. ${ }^{21}$ In French Copyright regime, the criteria of individuality and personality in a work could be seen as: 'the works reflects the "stamp of the author's personality, irrespective of its genre, form of expression, merit of its purpose, but taking into account the level of freedom the author has to exercise his creative choices...how much such intellectual contribution was put into the work." 22 Thus, it could be stated that the said individuality and personality closely relate to the creativity and intellectuals of the authors. Among other cases, the criteria of Skill, Judgment, and Labour are useful for giving reference to the originality of literature works, such as 'compilation.'

\section{The Idea-Expression Dichotomy}

The assessment of originality of a work is not on the "idea" of the work, but on the "expression" of such work, and this expression shall be created without copying from other existing work(s). This idea-expression dichotomy is stipulated under

${ }^{17}$ Jill Mckeough, et al., Intellectual Property, Commentary and Materials, Third Edition (Sydney: Lawbook Co., 2002), 58.

${ }^{18}$ Collins Concise Dictionary Plus (1989), s.v. "Labour”, Glasgow: William Collins Sons \& Co. Ltd.

19 David Vaver, Principles of Copyright, Cases and Materials (Geneva: World Intellectual Property Organization, 2002), 58.

${ }^{20}$ In Feist v.s. Rural, the selection and arrangement were considered as element of creativity.

21 Graham Dutfield, dan Uma Suthersanen, Global Intellectual Property Law (Glos, Cheltenham, UK: Edward Elgar Publishing Limited, 2008), 81.

22 Ibid., 82. 
Article 9 paragraph (2) of the TRIPS, and also Article 2 of the WIPO Copyright Treaty. Since copyright protection is not given to the idea, in order to prove that a work is not original - or copying from others, the plaintiff must claim that the 'expression' of his or her work has been copied by the defendant; thus, proving that the copying was on the 'expression,' and not the 'idea' of the work.

This means that a work which was created by inspiration of the same idea of the other works, but then resulted in different (or new) expression, such work can be considered as having the originality. There is jurisprudence to this doctrine in the case of Bauman v. Fussell (1978) R.P.C. 485 (U.K.: County Court \& Court of Appeal, 1953). In the case, the defendant, being inspired by the photograph of two fighting roosters captured by the plaintiff (who is a photographer), created a painting from the photograph. It was undoubtedly considered by the judge that the defendant was inspired by the plaintiff's photograph. However, the defendant had created new form of expression through the making of painting, and inside it, he also added some degree of different interpretations on the two fighting roosters' scene. These considerations then make the painting could be called as original. ${ }^{23}$

\section{E. The Theories of Circumstantial Evidence}

Departing from the concept that originality is 'originated from the authors' - as not copying from others' works, ${ }^{24}$ the theories in circumstantial evidence test a work's originality through two elements. These elements are to prove of whether the work, through copying of other existing work(s), infringes copyright and so making it not original. The said elements are "Access" and "Substantial Similarity," which are used to support argumentations of non-mechanical copying, because sometimes the copying are conducted through non-physical tools, such as memories. Therefore, they serve as 'circumstantial evidences' ${ }^{25}$ in cases of copyright infringement. The first element, 'Access,' is to observe of whether the author has the reasonable opportunity to see, hear, or copy, either directly or indirectly, of other existing works. ${ }^{26}$

Of all the circumstances that could indicate the 'Access' are when the works become the hits or popular among the consumers or public society, so that the alleged infringers can hardly deny the exposure of such works in the market. For instance, a popular song will be often air-played in the Radio or broadcasted through TV, and

${ }^{23}$ On the case - Judge Dale: I think these factors bring in the art of the artist here and show that he has used the plaintiff's work as an inspiration; that he has not copied it, but has made a new work of art of his own. Even so, (as coming from a dissenting opinion in the same case) to judge different expressions resulted from the same idea can sometimes be complicated because when the first created work is having high degree of characteristics and specialties, the later works created can be considered as reproductions of the first work (David Vaver, 24-26).

${ }^{24}$ A copying activity which makes the created work is not original, includes those of mechanical copying, as well as deliberate copying during the process of creation. See Hendra Tanu Atmadja, Hak Cipta Musik atau Lagu (Jakarta: Program Pacasarjana, Fakultas Hukum, Universitas Indonesia, 2003); and Paul Goldstein, Copyright, Principles, Law and Practice, Volume II (Boston, Toronto, London: Little Brown and Company, 1989).

${ }^{25}$ The theory of circumstantial evidence could be read on the book of Hendra Tanu Atmadja, Hak Cipta Musik atau Lagu, and Mark Halloran (editor), The Musician's Business and Legal Guide, in where the theory is used to prove copyright infringements of musical works, including songs.

${ }^{26}$ Quoting from Mark Halloran's 'The Musician's Business and Legal Guide': Access means that the composer of defendant's song had a reasonable opportunity to hear plaintiff's song or view a print version of it before writing defendant's song (Mark Halloran, The Musician's Business and Legal Guide, ed. (Engelwoods Cliffs, New Jersey: Prentice Hall, 1991), 67). 
there would be a highly possible chance for an alleged infringer to hear the song; that it would be unreasonable if he/she denied such access to the song. It would be a different case if the song is not popular and distributed only within some small regions, that an exposure and easy access to the song will be reasonably difficult. In such case, the alleged infringer may not have the said 'Access' to the works, and thus, may prove that he/she did not copy the works. Other possible way of evidencing 'Access' is when the plaintiff can prove that the alleged infringer once had a direct 'Access' to the works, for example during the auditions or selections to judge the works, or if the plaintiff had given the copy of the works for certain purpose, such as a 'demo' record to the music producer or record labels, or as samples to the business relatives or connections. ${ }^{27}$

The second element, 'Substantial Similarity,' is to observe the similarity between the work with others, and although there is no strict definition of what is called as substantially similar, a work could be considered similar to others, if there is part(s) of it that is same/similar to others, and such similarity does not have to be in high quantity. The substantial similarity is less than identical, but it is more than a little bit alike, ${ }^{28}$ and this could indicate high probability of copying. However, the 'Substantial Similarity' only is not enough to fulfill a circumstantial evidence, in which evidencing 'Access' is also required. It could happen that the two works are similar, as coming from a same/similar inspiration or idea, but both of them did not have 'Access' to each other's work, so that a copying activity can hardly be proven (or even such copying may in fact does not exist). ${ }^{29}$

\section{F. The Independent Creation Theory}

This theory deems a work to have the originality, if the author creates the work independently, and he/she does not copy from other existing works. This means that the work does not have to be novel. So long it is created independently, the work may be considered as 'original.' The independent creation here shall mean free of any mechanic copying or conscious copying, and the said authors must be able to prove such independency. ${ }^{30}$ A jurisprudence from the case of Ty, Inc. v. GMA Accessories, Inc., 132 F.3d 1167 (U.S.: Court of Appeals, $7^{\text {th }}$ CIR. 1997), provided hints on deciding whether certain work was created independently basing on the artistic and aesthetic value of the alleged copying work. If the previous work, from which the later work is alleged copying, has distinguished characteristic, shapes, or specialties that are 'not to anything in the public domain,' then substantial similarity existed could indicate the

27 Ibid., 68.

28 As regards to the song works, Mark Halloran said: “...so similar that an ordinary listener to music would believe that there was a strong possibility that one song, or at least an important part of it, was copied from the other." Ibid.

${ }^{29}$ An exception to evidencing of 'Access' is in the case of the substantial similarity between the works are so overwhelming, strikingly similar, so that there could not be any doubt that such striking similar was occurred because of copying activity (Mark Halloran, 69; and Sherman, Musical Copyright Infringement, at. 84 n. 15, in Paul Goldstein, Copyright, Patent, Trademark and Related State Doctrine- Case and Materials on the Law of Intellectual Property, 774, in Hendra Tanu Atmadja, 118-119).

30 Databases and the Law, Copyright Protection Generally; available at http://www.unc.edu/ courses/2006spring/law/357c/001/projects/dougf/node4.html; Internet; accessed on 4 September 2009. Documentation or recordation during process of creation is important to prove the author's independent creation (Richard D. Fladung, Developing and Preserving Evidence of Independent Creation in Defense of a Copyright Infringement Lawsuit; available at http://www.martindale.com/legalmanagement/ article_Strasburger-Price-LLP_634280.htm; Internet; accessed on 11 March 2009). 
later work may copy the previous work. ${ }^{31}$

Other jurisprudence in the case of Francis Day \& Hunter Ltd v. Bron (1963) Ch. 587 (U.K.: Court of Appeal) dealt with 'conscious' and 'unconscious' copying. In the case, two song works created by the parties sounded similar to each other. Bron, as the alleged infringer, admitted that he had never heard the plaintiff's song consciously, even though because of the song's popularity, Bron might happen to hear the plaintiff's song unconsciously. The judge then decided than Bron created the song independently, even though during the creation process, Bron must had unconsciously copied the plaintiff's song. The jurisprudence distinguished a 'conscious' copying with those of 'coincidence' and 'unconscious' copying. The key point is to consider the author created the work independently, if he or she did an 'unconscious' or 'coincidence' copying, in which he or she must not be aware that he/ she had conducted a copying activity during the process of creating the work. Thus, a work is still having the originality, if the similarity to other works was resulted from 'unconscious' or 'coincidence' copying. ${ }^{32}$

\section{The Aspect of Originality in Music Studies}

In relation with song works, to determine the most suitable criteria in analyzing and defining the originality, it is important to study about the elements of songs. The discussion then will take into account the concept, characteristics, and criteria of songs' 'originality' based on music studies.

\section{A. Basic Elements of A Song}

In accordance with music theory, a song is considered different with music, because music has much broader concept than the song. In this research, the elaboration will be focusing on song works (or 'songs') only. Under the Indonesian Copyright Act, 'the song or music, either with or without the text' is protected. ${ }^{33}$ Based on music theory, songs contain text/lyric, and has the element of vocal in it, while music without text is usually called as 'composition.' This means that the Indonesian Copyright Act protects not only songs with lyrics/texts, but also compositions (or music without text).

Furthermore, the Indonesian Copyright Act protects the song in its entirety, encompassing the elements that form a song, which are the melody, lyric, arrangement, and notation. ${ }^{34}$ The protection applies to a song as a (one) work, and its elements cannot be protected separately. However, in music studies there are different concepts on the elements which form a song, they are: melody, lyrics, arrangement and notation. Melody is chain of tones (with high and low pitches/tones) which can be arranged into music or song. Lyrics come with vocals filling the compositions. The arrangement of a song relates with process of combining, consolidating, arranging compositions played with different musical instruments with or without the vocals. ${ }^{35}$ The New Harvard Dictionary of Music refers arrangement as:

\footnotetext{
31 David Vaver, 136-137.

${ }^{32}$ Ibid., 138.

${ }^{33}$ Article 12 paragraph (1) d of Indonesian Copyright Act No. 19 Year 2002, and Article 40 paragraph d of Indonesian Copyright Act No. 28 Year 2014.

34 The elucidation of Article 12 paragraph (1) d of Indonesian Copyright Act No. 19 Year 2002, and Article 40 paragraph d of Indonesian Copyright Act No. 28 Year 2014.

${ }^{35}$ See Pono Banoe, Kamus Musik (Yogyakarta: Kanisius, 2003), s.v. "Aransemen."
} 
(1) the adaptation of a composition for a medium different from that for which it was originally composed, usually with the intention of preserving the essentials of the musical substance; also the result of such a processs of adaptation.

(2) In such repertories, it is usually assumed that the composer's role has been to specify the melody and to name the accompanying harmonies in a rather straightforward way, leaving the arranger complete freedom with respect to performance medium and orchestration, and considerable latitude with respect to rhythmic and harmonic detail." 36

It could be concluded that arrangement of songs encompasses activities of arranging and/or adapting compositions of songs or music (with or without vocals) based on the essence of the original composition or melody (with or without lyrics) firstly created by the author or composer. This means that for an original composition or melody of a song, there could be different versions of music arrangement, yet with the same musical essence of the said composition or melody. This then leads to different textures of musical arrangement. Based on music theory, the music texture can be monophonic, polyphonic, and homophonic, and this is also influenced by the layers of melody and chords on the song, which then can fill each other, resulted in interweaving of sound. ${ }^{37}$ Different uses of musical instruments can also create different versions of arrangement.

Notation refers to writings of musical symbols, being as guides for performers on how to perform or play the music or songs. Different performers can have different interpretations on the notations, although the musical essence remains the same. Therefore, for one notation of a song containing melody and lyrics, there could be different arrangements played with varied instruments across the genre. ${ }^{38}$ Further, there is also a part called as motive in a song, and this is formed by the element of rhythm and melody as patterns. This motive in a song can be repeated continuously, or detached in parts of the song or compositions, yet can be recognized as having certain essence or substance of the song or composition. The motive, then, could become the basic texture of the song and can have function as identity of the song or composition. If the motive is unique and easily remembered, it could be a distinguished identity, or a substantial and/recognizable part(s) of a song work. Whenever a song becomes a hit, people can easily recognize the song from (parts of) motive of the song. ${ }^{39}$

\section{B. A State of Originality}

In the process of creating a song, the author may seek idea or inspiration from listening to others' music. By listening to music across the genre, sometimes they can

\footnotetext{
${ }^{36}$ Don Michael Randel, ed., The New Harvard Dictionary (Cambridge, Mass: Belknap Press of Harvard University Press, 1986), s.v. "Arrangement."

37 When a melody is accompanied by chords, the result is an interweaving of sound, melody is the horizontal strand; the chordal harmonies are the vertical strands. Daniel T. Politoske, Music (New Jersey: Prentice-Hall Inc., 1988), 37. However, different layers of non-imitative melody in a song sometimes may make it difficult to indicate the substantial

${ }^{38}$ Genre of music relates with the rhythms, which could be polka, march, passodoble, tradisional-waltz, vienese-waktz, english waltz, polonaise, swing, foxtrot, old society, blues, twist, jazz-rock, and others, basing on the beat, accent or tempo of the arrangement (Pono Banoe, s.v. "Irama." and Roger Kamien, Music An Appreciation: Third Brief Edition, Cynthia Ward, et al., ed., (Boston: Mcgraw-Hill, 1998), 32-35).

${ }^{39}$ Pono Banoe, s.v. "Motif."
} 
experiment and dig further to their musical creativities in order to create a desired, original song. Referring to the case of Francis Day \& Hunter Ltd v. Bron (1963) Ch. 587 (U.K.: Court of Appeal), either conscious or unconscious copying is possible to happen during the process of song creation, considering the author/composer seeks idea or inspiration from listening to other songs. However, in music studies, this can also relate to the sonorous image of a song, which refers to the combined sound of (the whole) song's elements arranged by the author or composer. It is crucial not to make the sonorous image sounded similar to other songs. Since the process of creation also involves the author/composer's instinct or imagination in combining the elements, there could be such risk of unconscious copying to other songs' sonorous image. ${ }^{40}$

The criteria of originality of song works may require different standards with the originality of other types of works, because as also like the other works, the process of creation requires different creativity, skills, imagination, and artistic value. Even in the context of musical studies, debates also have been going on to determine the standard criteria of originality. Among all the arguments, the originality of songs cannot be valued quantitatively; rather, it is a qualitative assessment. The music theory considers a song as being 'original' (has the 'originality'), if the song is fresh and new. This means that the song is sounded different with other existing songs. To make it different with others, a song should have a different combination of elements, and this means that it should contain a different combination or harmonization of melody, rhythm, and arrangement, including different patterns of motive compared with the other existing songs. The differences will make the song sounded different, and in other words, fresh and new.

Moreover, based on the music perspective, to judge whether a song is different with others, it is not seen as quantitatively. It is possible for a song to have some similar combination of elements with others, but still sounded different. Therefore, the judgment is on how qualitative is the song sounded similar to others, and how substantial is the part of the song that is similar to others. ${ }^{41}$ Even though the elements forming the songs are the same, they can be combined differently resulting in a song sounded qualitatively different with others. ${ }^{42}$ A song's originality is assessed in its relation (relational) with the other songs, since the judgment departs from its similarity with the others. Therefore, it could happen that one song is considered highly original (as obviously sounded different with others), or slightly original (with some substantial parts sounded similar to others). ${ }^{43}$ The music theory also considers the 'relevant facts' in judging a song's originality. For instance, song A is similar to song $B$, but both authors of A and B have never been met before, and each has never been heard of another's song before. This means that the similarity is a coincidence, and there is no proof that either A or B copied another's song. Based on this 'relevant fact,' both the songs are considered 'original. ${ }^{44}$

${ }^{40}$ Aaron Copland, Music and Imagination (New York: The New American Library of World Literature, Inc., 1959), 31-33.

41 "...for it to be original it must be qualitatively different in some respect from any previously known instance of that type." Aaron William et all., Creativity, Orginality, and Value in Music Performance dalam Musical Creativity, Multidisciplinary Research in Theory and Practice, Irene Deliege dan Geraint A. Wiggins, ed. (New York: Psychology Press, 2006), 167.

${ }^{42}$ Edy Husni, Lecturer of Music Studies in Universitas Negeri Jakarta, Interviewed by the writer, on 14 December 2009.

43 "Something is significantly original if it is readily distinguished from others of its type in the eyes of a third party", Aaron William, 168.

${ }^{44}$ Ibid. 


\section{Applying the Appropriate Criteria of Originality of Song Works}

According to the state of originality in music studies, not only the resulting sound that should be qualitatively different, but also the facts during the process of creation should indicate that there are no copying activities of other songs happened during the process. This means the required criteria of originality assessing: the result (the song's created at its final version) and the process of creation. Further criteria are also to assess the originality as qualitatively, and not quantitatively.

In regards to this, the elucidation of Article 15 (a) of Indonesian Copyright Act No. 19 Year 2002 mentions that allegation of copyright infringement should be considered qualitatively, since a quantitative measure will be difficult to assess on infringement of works. For instance, copying of substantial parts; regarded as characteristic, of other works (even though less than $10 \%$ ) could be alleged as an infringement. This means that if a song is qualitatively sounded similar to other song(s), then it could be an infringement to the other song's copyright, and the song could be considered not original (copying/imitating from the other song). Furthermore, the Indonesian Copyright Act No. 28 Year 2014 also refers infringement to copyrights as either utilization of whole or substantial part of the work, and considers utilization of works by others by measuring the substantial part (of the work) that is being used or imitated/copied. The substantial part refers to the most important and most unique part of a work that characterizes it. A work which copies (a whole or substantially of) others, and thus infringing copyright, cannot be regarded as having the originality. This shows that essentially the assessment to the song's originality lies down on a qualitative (substantially) basis.

In this respect, the Indonesian Copyright Act and music studies are having comparable criteria on songs' originality, which are: (1) a qualitatively substance (substantial) assessment on the results, and an assessment to the process of creation of whether it is originated from the authors, considering the relevant facts. Recalling back to the various doctrines, jurisprudences, and theories of originality, those which are appropriate based on the Indonesian Copyright Act and music studies, are the Theory of Circumstantial Evidence and the Independent Creation Theory. The basic considerations of using these two theories are as followed:

1. The Theory of Circumstantial Evidence applies two criteria: (a) Substantial Similarity, and (b) Access. These two criteria can assess on the result (the created song), and the process during creation. First, the song should not have any substantial similarity with other existing songs. If it has such similarity, which may indicate that there is 'Substantial Similarity, then it is possible that the author has copied from other songs. To prove further whether such copying happened during the process of creation, the criteria of 'Access' shall be proven. This means that if there is no reasonable opportunity of having the 'Access', although there is 'Substantial Similarity,' the author is considered not copying from others, and the song will be considered as 'original.'

2. To prove that the similarity is not occurred because of copying, the author must also prove that he/she (in the process) created the song independently. The Independent Creation theory becomes the basis to assess the author's independency in creating the song, considering also the relevant facts on such process. Such independency shall not only mean that he/she did not mechanically copy the song, but also did not consciously copy the song. This means that if the similarity occurs because of any coincidence or unconscious copying, the song 
may still be considered 'original,' yet, basing also on the evidencing of the facts presented before the court.

\section{An Assessment Example on the Song's Originality: Similarity of Songs by Domino and Muse}

To provide an example assessment of song's originality, in 2009 an Indonesian band named Domino released its single titled "Siapa yang Pantas." Apparently most consumers in Indonesia considered the song sounded similar with a song from UK's band, Muse, titled "Starlight," which was released in 2006. Starlight is one of Muse's songs that become a hit, with such an easy listening and memorable beat and melody, Starlight has this distinguished song motive that becomes the song's identity. Even though in both songs the melody is quite different with each other, Domino's rhythmic motive (the drum beats and bass arrangement) is similar with Starlight, which rhythmic is one of Starlight's distinguished motive. Therefore, when most people first hear Siapa yang Pantas by Domino, they thought they are going to hear Starlight, however in fact, it was Domino's song. ${ }^{45}$ The similarity in rhythmic motive of both songs create similar sonorous image.

Recalling back to the elements forming a song, the arrangement of a song involves melody and rhythm of the song, and the combinations of both elements can result in the song's motive. The similarity in Starlight and Siapa yang Pantas lays in the rhythmic motive (the rhythm pattern), involving the drum beats and guitar bass arrangement. To assess whether Domino's Siapa yang Pantas has the originality, the criteria will depart from the theory of circumstantial evidence and the independent creation theory.

1. Access

Becoming a hit song, Starlight was widely exposed to the public. Although the song comes from UK's band, but it was also distributed, disseminated, and communicated in Indonesia. Indonesian people can access the song's album in music stores, and it was also often played in Radio or TV programs. In 2007, Muse also came to have live concert in Indonesia, where the song Starlight was also performed. Judging from the facts, it can be assumed that Domino had a proper Access to Starlight.

2. Substantial Similarity

As aforementioned, the similarity between both songs is in the rhythmic motive. Observation indicated that such rhythmic motive of Starlight, which is similar to Siapa yang Pantas, is one distinguished quality of Starlight, so that it functions as one identity to the song. This means that the rhythmic motive can be considered as a qualitatively substantial part of Starlight. Therefore, this is possibly why most people thought that Domino was plagiarizing Muse, considering such similar substantial part of Starlight song with Siapa yang Pantas.

3. Independent Creation

To prove that they were not copying Starlight, Domino has to prove that they created Siapa yang Pantas independently. Such independent creation could be proven through documentation or recordation of their process of creating and recording of song. A prove that they were not mechanically copy Starlight can indicate such independent creation. However, it should also be carefully taken

${ }^{45}$ This is based on some spontanious interviews that the writer conducted to some people, not necessarily a huge fan of music. 
into account, which a conscious (non-mechanical) copying could happen. For example during the process of sound recording production, Domino had aware that Siapa yang Pantas sounds similar to Starlight, but they ignored such similarity, then an independent creation may not be acknowledged in that case.

In that sense, such case provides an example assessment to the originality of songs.

\section{VI.Conclusion}

Generally, with regard to most cases of originality, several doctrines and/or theories which are used to determine the criteria of originality of works are the followings:

a. Sweat of the Brow (Industrious Collection);

b. Creativity School;

c. Skill, Judgment, and Labour;

d. The Idea-Expression Dichotomy;

e. The Theory of Circumstantial Evidence, and

f. The Independent Creation Theory.

Based on the elaboration on such doctrines and/or theories aswell as jurisprudences of originality, and also by taking into account the elements forming a song, as well as originality based on music study and/or perspective, the most suitable criteria to analyze and define the originality of songs are: (a) the Theory of Circumstantial Evidence, with focus on the criteria of "Access" and "Substantial Similarity;" and (b) the Independent Creation Theory. The application of these two theories are also in line with the provision of Indonesian Copyright Act, which requires an original work as originated from the authors, having his/her uniqueness and personality coming from his/her creativity, skills, capabilities and such (which is an assessment to the process of creation), and that the work should not substantially and qualitatively copy others, which is an assessment to the result.

To sum up, a song work can be considered as 'original' (has the 'originality') if: such song is made based on the author's independent creation, which contains creativity, skills, and intellectuals of the author, and the song, substantively and qualitatively, is not sounded similar or same to other existing song(s), and if indeed there are parts of the song sounded similar or same with other existing song(s), such similarity should not occur on purpose, or under the conscious thought of the author.

The criteria of originality for a song involve assessment on the process of its creation, and the substance of its end results, which can be measured using the Theory of Circumstantial Evidence, and the Independent Creation Theory. The use of these two theories is not in contrary to the Indonesian Copyright Act, rather, help providing legal references.

\section{Bibliography}

\section{Regulations:}

World Intellectual Property Organization (WIPO). Rome Convention for the Protection of Performers, Producers of Phonograms, and Broadcasting Organizations, 1961. 
Berne Convention on the Protection of Artistic and Literary Works Year 1886 (as amended on 1979). Ratified by Presidential Decree of Republic of Indonesia No. 18 Year 1997 concerning Ratification of Berne Convention for The Protection of Literary and Artistic Works.

World Intellectual Property Organization (WIPO). WIPO Performances and Phonograms Treaty, 1996. Ratified by Presidential Decree of Republic of Indonesia No. 74 Year 2004 cocnerning Ratification of WIPO Performances and Phonograms Treaty.

Indonesia. Undang-Undang tentang Hak Cipta. Act No. 19 Year 2002. State's Gazette No. 85 Year 2002. Addition to the State Gazette No. 4220.

Indonesia. Undang-Undang tentang Hak Cipta. Act No. 28 Year 2014. State's Gazette No. 266 Year 2014. Addition to the State Gazette No. 5599.

\section{Books:}

Abbott, Frederick, and Thomas Cottier. 1999. The International Intellectual Property System: Commentary and Materials, Part One. Kluwer Law International. In the Reading Material: Hak Kekayaan Intelektual. 2007. Depok: Fakultas Hukum Universitas Indonesia Program S.1.

Ali, H. Zainuddin. 2009. Metode Penelitian Hukum. Jakarta: Sinar Grafika.

Ali, Matius. 2006. Seni Musik SMA Untuk Kelas X. Jakarta: Erlangga, 2006.

Audah, Husain. 2004. Hak Cipta dan Karya Cipta Musik. Bogor: PT. Pustaka Litera Antar Nusa.

Bari Azed, Abdul. 2006. Kompilasi Konvensi Internasional HKI yang Diratifikasi Indonesia. Jakarta: Director General of Intellectual Property Rights, Department of Law and Human Rights, in cooperation with Publisher of Faculty of Law University of Indonesia.

Blatter, Alfred. 2007. Revisiting Music Theory, A Guide to the Practice. New York: Routledge, Taylor \& Francis Group.

Copland, Aaron. 1959. Music and Imagination. New York: The New American Library of World Literature, Inc.

Damian, Eddy. 2002. Hukum Hak Cipta. Bandung: PT. Alumni.

Derclaye, Estelle. 2009. Research Handbook on the Future of EU Copyright (Research Handbooks in Intellectual Property). Cheltenham, UK: Edward Elgar Publishing Limited.

Dutfield, Graham, and Uma Suthersanen. 2008. Global Intellectual Property Law. Glos, Cheltenham, UK: Edward Elgar Publishing Limited.

Goldstein, Paul. 1989. Copyright, Principles, Law and Practice, Volume II. Boston, Toronto, London: Little Brown and Company.

Halloran, Mark. ed. 1991. The Musician's Business and Legal Guide. Engelwoods Cliffs, New Jersey: Prentice Hall.

Indonesia-Australia. 2005. Specialised Training Project-Phase II (Proyek Pelatihan Khusus-Bagian II), Intellectual Property Rights (Hak Kekayaan Intelektual). Australian Government-AusAID, State Secretariat Republic of Indonesia, Hassal \& Associates International.

Intellectual Property Law, Fifth Edition. 2006. United Kingdom: Routledge-Cavendish. Kamien, Roger. 1998. Music An Appreciation: Third Brief Edition. Cynthia Ward, et al. ed. Boston: Mcgraw-Hill. 
Kodijat-Marzoeki, Latifah. 2007. Istilah-Istilah Musik. Jakarta: Djambatan.

Leaffer, Marshall. 1998. Understanding Copyright Law. New York: Matthew Bender \& Co.

Lindsey, Tim, et al. eds. 2005. Hak Kekayaan Intelektual, Suatu Pengantar. Bandung: PT. Alumni.

McKeough, Jill, and Andrew Stewart. 1997. Intellectual Property in Australia. Butterworths. In the Reading Material: Hak Kekayaan Intelektual. 2007. Depok: Fakultas Hukum Universitas Indonesia Program S.1.

Mckeough, Jill, et al. 2002. Intellectual Property, Commentary and Materials, Third Edition. Sydney: Lawbook Co.

Narkubo, Cholid, and Abu Achmadi. 2004. Metodologi Penelitian. Jakarta: Bumi Aksara.

Politoske, Daniel T. 1988. Music. New Jersey: Prentice-Hall Inc.

Scassa, Teresa, and Michael Deturbide. 2004. Electronic Commerce and InternetLaw in Canada. David Iggulden. ed. Canada: CCH Canadian Limited.

Soekanto, Soerjono. 2007. Pengantar Penelitian Hukum. Jakarta: UI-Press.

Sunggono, Bambang. 2007. Metodologi Penelitian Hukum. Jakarta: PT Raja Grafindo Persada.

Tanu Atmadja, Hendra. 2003. Hak Cipta Musikatau Lagu. Jakarta: Program Pacasarjana, Fakultas Hukum, Universitas Indonesia.

Vaver, David. 2002. Principles of Copyright, Cases and Materials. Geneva: World Intellectual Property Organization.

Widjaja, Sendjaja. 2007. Hits Maker, Panduan Menjadi Produser Rekaman Jempolan. Jakarta: PT. Elex Media Komputindo.

William, Aaron, et al. 2006. Creativity, Orginality, and Value in Music Performance in Musical Creativity, Multidisciplinary Research in Theory and Practice. Irene Deliege and Geraint A. Wiggins. ed. New York: Psychology Press.

\section{Interviews:}

Damarsasongko, Agung. Head Section of Legal Consideration Directorate Copyright, Director General of Intellectual Property. Department of Law and Human Rights: Director General of Law and Human Rights.

Husni, Edy. Lecturer of Music Studies State University of Jakarta. Faculty of Art and Literature.

Sundah, James F. Chairman of the Department of Information and Teknologi, the Association of Singers, Authors, and Arrangers of Indonesian Sound Recording, also a musician.

\section{Dictionaries:}

Banoe, Pono. 2003. Kamus Musik. Yogyakarta: Kanisius.

Collins Concise Dictionary Plus (1989). Glasgow: William Collins Sons \& Co. Ltd.

Garner, Bryan A. ed. 1999. Black's Law Dictionary, Seventh Edition (1999).

Poerwadarminta, W.J.S. eds. 1989. Kamus Umum Bahasa Indonesia. Jakarta: Balai Pustaka.

Randel, Don Michael. ed. 1986. The New Harvard Dictionary of Music. Cambridge, Mass: Belknap Press of Harvard University Press. 


\section{Journals, Articles, and Other Sources:}

Baran, Madeleine. Copyright and Music: A History Told in MP3, http://www.illegal-art. org:audio:historic.html; Internet; 4 February 2010.

Copyright Protection Generally. Databases and the Law, Prof. Laura Gasaway's Cyberspace Law course at the UNC School of Law for Spring, 2006; http:// www.unc.edu/courses/2006spring/law/357c/001/projects/dougf/node4. html; Internet; 9 April 2009.

Databases and the Law. Copyright Protection Generally; http://www.unc.edu/ courses/2006spring/law/357c/001/projects/dougf/node4.html; Internet; 4 September 2009.

Drassinower, Abraham. Sweat of the Brow, "Creativity, and Authorship: On Originality in Canadian Copyright Law," University of Ottawa Law and Technology Journal (2003-2004): 107-108.

Eriana Safira, Devi. Ketika Plagiasi Menjadi Sebuah Kutukan; http://devieriana. wordpress.com/2009/08/09/ketika-plagiasi-menjadisebuah-kutukan/; Internet; 7 April 2010.

Fladung, Richard D. Developing and Preserving Evidence of Independent Creation in Defense of a Copyright Infringement Lawsuit; http://www.martindale.com/ legal-management/article_Strasburger-Price-LLP_634280.htm; Internet; 11 Maret 2009.

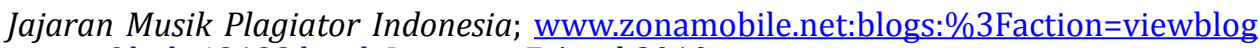
\&bid=43123.html; Internet; 7 April 2010.

Musik Indonesia Plagiat? Introspeksi Buat Musik Kita; http://www.kaskus.us/ showthread.php?p=122781951; Internet; 7 April 2010.

Parchomovsky, Gideon dan Alex Stein. Originality. Virginia Law Review 95, May 2009.

P.S., Berliana. "Aspek Hukum Penyiaran Sinetron yang Dianggap Tiruan Ditinjau dari Undang-Undang Hak Cipta." (Undergraduate Thesis: University of Indonesia, Depok,2004).

Queen, Biography; http://www.rollingstone.com/artists/queen/biography; Internet; 14 April 2010.

Scasaa, Teresa. Original Facts: Skill, Judgement, and the Public Domain. Presented at Intellectual Property Scholars Workshop, University of Western Ontario, 20- 22 January 2005); http://lawjournal.mcgill.ca/documents/1224868339_Scassa. pdf; Internet; 2 October 2009.

The Concept of Originality-Different National Approcahes; http://www.juridicum. su.se/jurweb/utbildning/master/master_of_european_intellectual_property_ law/Material\%202009/Module\%201/Summaries/Copyright/Wenske_2.pdf; Internet; 4 September 2009.

U.S. Copyright Law Precedent. Feist Publication, Inc. v. Rural Telephone Service Co.; http://www.solarnavigator.net/USA_copyright_precedent_feist_v_rural.html; Intenet; 11 September 2009.

US Supreme Court Center. Feist Publications, Inc. v. Rural Telephone Service Co.; http:// supreme.justia.com/us/499/340/case.html; Internet; 2 October 2009. 